\title{
A Comprehensive Model for Integrating Entrepreneurship Education and Capstone Projects while Exceeding ABET Requirements
}

John B Ochs, Professor and Director of the IPD Program, Lehigh University Gerard P. Lennon, Professor and Associate Dean of Engineering, Lehigh University Todd A Watkins, Associate Professor, Department of Economics, Lehigh University Graham Mitchell, Director of the Entrepreneurship Program, College of Business and Economics, Lehigh University

\begin{abstract}
Imagination, creativity, innovation, invention and venture--a sequence of professional development for $21^{\text {st }}$ century renaissance engineers and technical entrepreneurial business people, designed to give engineering and business students the skill sets to compete in our global economy with its ever-increasing rate of technical and financial change. A technical entrepreneurship minor started at Lehigh University in the Fall 2004 semester is now in full swing and available to all undergraduates, including all engineering and business students. The five-course program includes two final project courses, which students can take as a capstone experience. To date, several pilot teams have successfully completed the sequence, completed their undergraduate engineering requirements and used the capstone courses to develop products and undertake business planning for their start up technical ventures. In addition to the courses in the entrepreneurship minor, infrastructure is in place to support a Student Entrepreneurship Competition in which student teams can develop prototypes and their ideas into business plan proposals for several sources of possible seed funding. The infrastructure includes a mentoring entrepreneurs' network of Lehigh alumni, an on-campus student-start-up incubator, and new early-stage follow-up funding. This paper will describe the integration of the capstone courses with the entrepreneurship minor and show examples of student start-up companies from Civil and Environmental Engineering, Computer Science and Engineering, and Integrated Business and Engineering. The paper will explore how these companies started as part of the ABET-approved capstone design courses, which significantly exceed the minimum ABET requirement of a major design experience while working in a multidisciplinary team. This model is expanded to show how the plan can be applied to all engineering disciplines.
\end{abstract}

Keywords: Engineering Entrepreneurship Education, Capstone Courses, ABET

\section{A. Lehigh University}

\section{Introduction, Background and Rationale}

The 1,600 acre campus of Lehigh University is located in Bethlehem, PA, 75 miles west of New York City and 50 miles north of Philadelphia. The university is private, coeducational, non-denomination and serves 4,650 undergraduates and 1,980 graduate students with $\sim 60 \%$ percent male and $40 \%$ female. Students are enrolled in 3 undergraduate colleges: arts and science $(50 \%)$, business $(20 \%)$, engineering $(30 \%)$ with a graduate college of education. Lehigh is considered to be in the class of "highly 
selective" schools with a combined SAT scores ranging from 1210 to 1350 with over $50 \%$ of the student body receiving scholarships. The student body is from over 20 states and 65 countries with the majority of students coming from Pennsylvania, Delaware, New Jersey and New York. There are approximately 400 full-time faculty members with an 11:1 undergraduate student to faculty ratio. The University is a class R2 research school with annual research funding of $\sim \$ 40 \mathrm{M}$ with 24 research centers or research institutes. Lehigh has an active and engaged alumni serving in various capacities, such as industry liaisons, department and program advisors and members of the University Board of Trustees. Lehigh has consistently ranked in the top 10 nationally among research institutions in the Standard and Poor's survey of Fortune 500 companies in the percentage of Lehigh Alumni in corporate leadership positions.

\section{B. Entrepreneurship at Lehigh}

Lehigh University offers regular courses and full-time regular faculty as well as adjunct faculty (Lehigh calls them Professors of Practice) dedicated to teaching entrepreneurship. According to a Cornell University study by Debra Streeter [Ref 1] Lehigh's entrepreneurship model is classified as a magnet program centered in the business school and primarily MBA-oriented. Lehigh has made a substantial commitment to our entrepreneurship-oriented graduate MBA program, including an entrepreneurial option and a Venture series certificate program.

Recently Lehigh has invested heavily in several new programs that promote campus-wide teaching, research and outreach in technical entrepreneurship at the undergraduate level, including a year-long experiential capstone course for majors in Integrated Business and Engineering, Computer Science and Business, Bio Engineering, Design Arts and a catch all campus wide program in Integrated Product Development and the entrepreneurship minor.

Entrepreneurship teaching - undergraduate: Since the mid 1990's Lehigh has offered an award winning cross-disciplinary program in Integrated Product Development (IPD) for students in engineering, business and the design arts. For the past eight years the program has focused on technical entrepreneurship through new product development, with industry sponsorship of cross-disciplinary student teams [Ref 2]. The IPD program has also engaged local entrepreneurs and student entrepreneurs. Since the inception of the National Collegiate Inventors and Innovators Alliance (NCIIA), eleven Lehigh teams have won national competitions for collegiate innovation and entrepreneurship (see www.NCIIA.org). The IPD program is recognized as a truly unique cross-disciplinary educational experience [Ref 3] and it has grown to support over 200 students per year, working in competing teams of six students each. (See www.lehigh.edu/ipd for program details and list of projects). In 2005 Lehigh launched an entrepreneurship minor open to all undergraduates [Ref 4]. The sixteen-credit minor has been developed by a cross-disciplinary faculty committee with faculty representatives from engineering, business, arts and sciences, the Integrated Product Development Program (IPD), the Integrated Business and Engineering Program (IBE) and the graduate MBA vSeries seminars on new venture creation. The undergraduate minor program consists of four new courses and one existing prerequisite. The pedagogical approach is 
project-based, experiential learning, of the entrepreneurial mind-set distinct from minors in business or engineering. Support for student lead entrepreneurial projects comes from the University's Small Business Development Center, the Office of Technology Transfer, the Ben Franklin Technology Partners, the Keystone Innovation Zones (KIZ) of Pennsylvania and the NCIIA. As in the other experiential programs, the entrepreneurship minor concludes with a two semester practicum. In 2005 the fourth year of our campus wide Student Entrepreneurship Competition (SEC), seven student teams were selected as winners of small start up grants to develop their ideas into commercial ventures. These winners will work within the various undergraduate programs to develop their working prototypes and business plans as an integral part of their capstone courses or as part of technical electives in directed study or senior thesis.

Entrepreneurship teaching - graduate: Historically, entrepreneurship education at Lehigh has focused on the graduate MBA program in the College of Business and Economics. This program has recently implemented an entrepreneurial track led by an experienced and successful entrepreneur. The graduate MBA has been augmented by a combined MBA and Engineering Masters program, where students earn dual degrees in business and engineering. Also at the graduate level, Professor Ochs has offered a new product development course with industry-sponsored projects with a globally dispersed development team [Refs 5 and 6]. As mentioned above the MBA program now offers a certificate program in entrepreneurship called the Venture series or V-series. In addition, our Manufacturing System Engineering offers a graduate course for new product development with a corporate framework.

Entrepreneurship research: The College of Business and Economics has led the University in Entrepreneurship research through the Small Business Development Center, and Lehigh's Iacocca Institute for Global Entrepreneurship. Recent research and development in technical entrepreneurship at Lehigh has been funded by NASA/CAPE [Ref 7], the US Department of Education [Refs 8 and 9] and the US Department of Labor [Ref 10]. This funding has resulted in the development of the various curricula and has provided start-up funding for the IPD program and Entrepreneurship minor.

K-12 entrepreneurship outreach: The Integrated Product Development program has teamed with Lehigh's Iacocca Institute for Global Entrepreneurship (www.iacoccalehigh.org/cap/) to sponsor Career Awareness Programs (CAP) for highly qualified, underrepresented high school students. The focus of these one-week summer programs included business, engineering and design arts, all with a technical entrepreneurship focus [Ref 11]. In 2001 in conjunction with Lehigh's Global Village, the Lehigh team from the Iacocca Institute and the College of Education was awarded a grant for a Pennsylvania Governor's School for Global Entrepreneurship. This eight-week residential program brings over 80 highly qualified high school students to campus and combines them with 60+ entrepreneurs from Europe, Asia, Africa and South America. Finally, with considerable input from Lehigh's IPD program, the Community of Agile Partners in Education (CAPE), a Bethlehem PA based consortium of over 200 schools, received a Pennsylvania grant to develop a network of entrepreneurship educators at the high school, community college and university levels. This planning grant focuses on 
entrepreneurship education using Lehigh's Integrated Product Development model for technical entrepreneurship. In 2004 this model was implemented in a pilot program at Northwestern Lehigh High Schools that is now a required course for all juniors. [Ref 12]

Community Outreach: Lehigh University houses and supports a Small Business Development Center (SBDC), the Northeast Tier of the Ben Franklin Technology Center and the Manufacturing Resource Center. These state-sponsored centers help identify and assist company startups with legal, organizational, managerial and financial assistance, often using Lehigh students through courses such as Lehigh Management Assistance Counseling (LUMAC) and the Marketing Practicum. The Ben Franklin center also provides qualified companies national, award-winning on and off campus incubation centers. The centers have close relationships with the Lehigh Valley Economic Development Council, the Northeast Pennsylvania Angel Network and private investments groups in Northeastern Pennsylvania. For the 2002 project year, the clients for the undergraduate capstone courses mentioned above were individual local entrepreneurs from the eastern Pennsylvania region recruited in part through the SBDC and the Ben Franklin Center. Funding for this experiment was provided by the Department of Labor [Ref 10]. In 2005 state funding to the Keystone Innovation Zone of South Bethlehem has provided start up funding for several student entrepreneurial projects and companies.

\section{Changing role of engineers-Example Student start ups.}

The fact that the world is changing is evident. The fact that the rate of change is increasing is also obvious. The role that engineers play in this ever changing globally competitive world is also changing. The engineering student must evolve from a "problem solver" to an "opportunity and business creator." The engineer must go from a supporting role within the development process to the leader of that process. The engineer must no longer be educated to support and work in a corporate infrastructure but instead must be educated to develop new ones. The entrepreneurship mind set must be developed in this generation of graduates for our and their own economic survival.

The basic tenets of this mind set include the following:

1) Innovation fueled by creativity is this generation's economic development engine. In the slightly modified words of Lehigh Alumnus Lee Iacocca, "Innovate, automate, emigrate or evaporate."

2) The greatest opportunity for innovation occurs at the intersection of disciplines

3) New product development (and development of new services as well) is a process that can be taught and should be experienced.

4) An interdisciplinary development team provides the greatest chance of success.

5) An leader with an entrepreneurial mind set has the greatest possibility of successful progression from idea to commercial venture.

6) The best way to learn these skills is to "Just do it."

As examples of this mind set in student teams, in 2003 and 2005, EcoTech Marine and hField have been launched by student entrepreneurs. EcoTech Marine is led by two engineering students, Pat Clawson (BS Material Science '04) and Tim Marks (BS Civil 
and Environmental Engineering '04). A recent graduate of the on-campus student incubator, these gentlemen won the 2003 student competition, they won a NCIIA grant, a KIZ grant and have launched their company with their first order of 2000 units of their new circulating pump for reef aquaria. Figure 1 below shows a picture of their new product. Following a similar model but one year behind EcoTech Marine, hField is a student start up lead by Curtis MacDonald, a Computer Engineering major in the Integrated Business and Engineering program. Curtis and his band of student entrepreneurs have developed a USB antenna to extend wifi to 1000 feet. Figure 2 shows their prototype. Hfield too has received orders from local schools and the south side of Bethlehem to support wireless communities in the Lehigh Valley. Each of these teams is led by students who have developed the entrepreneurial mind set through course and first hand experiences these courses require.

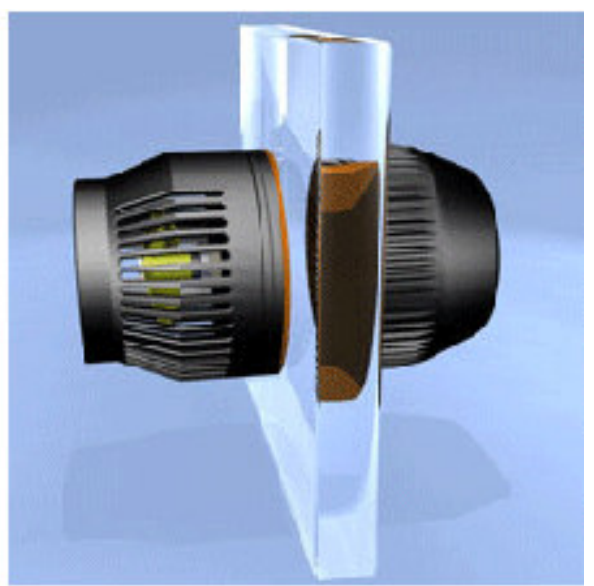

Figure 1. EcoTech Marine's circulating pump

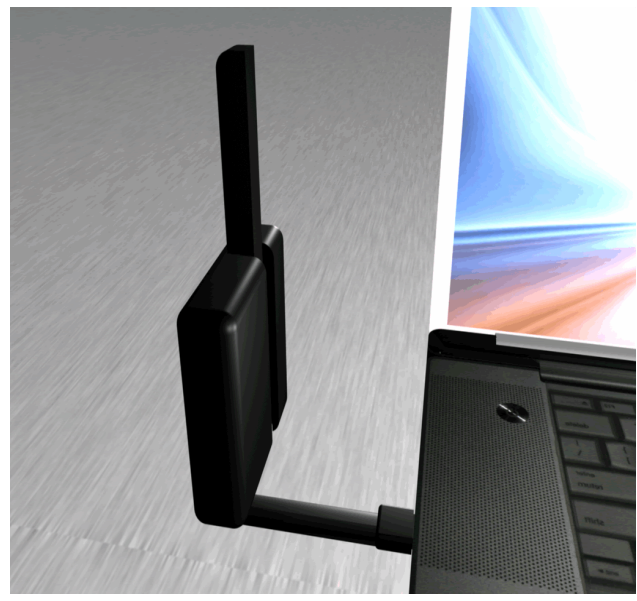

Figure 2. hField's USB wifi antenna.

\section{Defining the Entrepreneurial Mind Set}

The concept of entrepreneurship has evolved significantly over more than 300 years, so no single agreed-upon definition exists. However, in the Lehigh context, we favor that developed by one of the leading researchers and educators in the field, Howard Stevenson of the Harvard Business School:

- Entrepreneurship is "the pursuit of opportunity beyond the resources you currently control." [Refs 13-16]. We add in the title of our first course, that we conceive the root of entrepreneurship, whether in emerging or existing enterprises, as "Managing Discovery for Wealth Creation."

- Entrepreneurship is widely recognized as an academic field in its own right, with a huge research literature that spans, inter alia, organizational management, technology management, engineering management, economics, finance and marketing. The American Academy of Management has an entire division devoted to entrepreneurship. The American Society of Engineering Education does too. Babson College has become the leading undergraduate business program in the nation by focusing on an integrated curricular approach to entrepreneurship. The large number of existing educational programs in 
entrepreneurship is also testimony to the academic breadth, independence and rigor of entrepreneurship as an academic field of inquiry [Ref 16]

- Entrepreneurship differs from traditional business research and education in the nature of the problems, of the decision making processes and of the mindsets involved. In the Lehigh context, the curricular approach is guided by Stevenson's process definition, outlined conceptually in Table 1 below.

\begin{tabular}{|c|c|c|}
\hline Entrepreneur & $\begin{array}{l}\text { Key Business } \\
\text { Dimension }\end{array}$ & $\begin{array}{c}\text { Traditional } \\
\text { Manager/Administrator }\end{array}$ \\
\hline $\begin{array}{l}\text { Driven by perception of } \\
\text { opportunity }\end{array}$ & $\begin{array}{c}\text { Strategic } \\
\text { Orientation }\end{array}$ & $\begin{array}{c}\text { Driven by resources currently } \\
\text { controlled }\end{array}$ \\
\hline Quick commitment & $\begin{array}{l}\text { Commitment to } \\
\text { Opportunity }\end{array}$ & $\begin{array}{c}\text { Evolutionary with long } \\
\text { duration }\end{array}$ \\
\hline $\begin{array}{l}\text { Multistage decision-making with } \\
\text { minimal exposure at each stage }\end{array}$ & $\begin{array}{l}\text { Commitment } \\
\text { Process }\end{array}$ & $\begin{array}{l}\text { Single-stage with complete } \\
\text { commitment upon decision }\end{array}$ \\
\hline $\begin{array}{l}\text { Episodic use of rent of required } \\
\text { resources }\end{array}$ & $\begin{array}{l}\text { Control of } \\
\text { Resources }\end{array}$ & $\begin{array}{l}\text { Ownership or employment of } \\
\text { required resources }\end{array}$ \\
\hline $\begin{array}{l}\text { Flat with multiple informal } \\
\text { networks }\end{array}$ & $\begin{array}{l}\text { Management } \\
\text { Structure }\end{array}$ & Formalized hierarchy \\
\hline Value-based \& team-based & Reward System & $\begin{array}{l}\text { Resource-based individual } \\
\text { and Promotion Oriented }\end{array}$ \\
\hline \multicolumn{3}{|c|}{ Table 1. Stevenson's Process Definition of Entrepreneurship [Ref 13]. } \\
\hline
\end{tabular}

III. Integrated Product Development Model

\section{A. IPD process model}

According to Stevenson, "Almost everything we traditionally teach about management has to do with managing resources. To teach students to be entrepreneurs, we have to focus them on opportunities.... The entrepreneur, the person himself, is the key. His company is fueled by his knowledge, contacts, resources, and skills. Successful entrepreneurs have characteristics in common: tenacity, attention to detail, an motivates other people to take action."

Figure 3 shows the five phases of the product development model as espoused at Lehigh. Entrepreneurial start ups and established companies follow this process with the expressed desire to satisfy a customers needs and to create wealth for the company stakeholders including owners, employees, the community and the nation. Wealth is created when the company risks its resources at the start to create a product or service that will be purchased in the near future. An innovative company embraces this process and strives to be the best in class at implementing it.

In Phase 1, Opportunity Scanning, key people are always searching for new materials, the application of basic R\&D, new advances in manufacturing and the feedback from sales, service and customers on the need for new and improved products and services. These opportunities are captured, defined, prioritized and scored for potential value to the 
company. In over 14 years of seeking IPD projects from industry sponsors, we have met hundreds of engineers, project managers and company officers in dozens of successful companies. Each one we meet has their own "wish list" of new products that they wish they could develop. In IPD we help these ideas come to fruition. The entrepreneur takes on these projects and seeks the resources needed to bring it to reality.

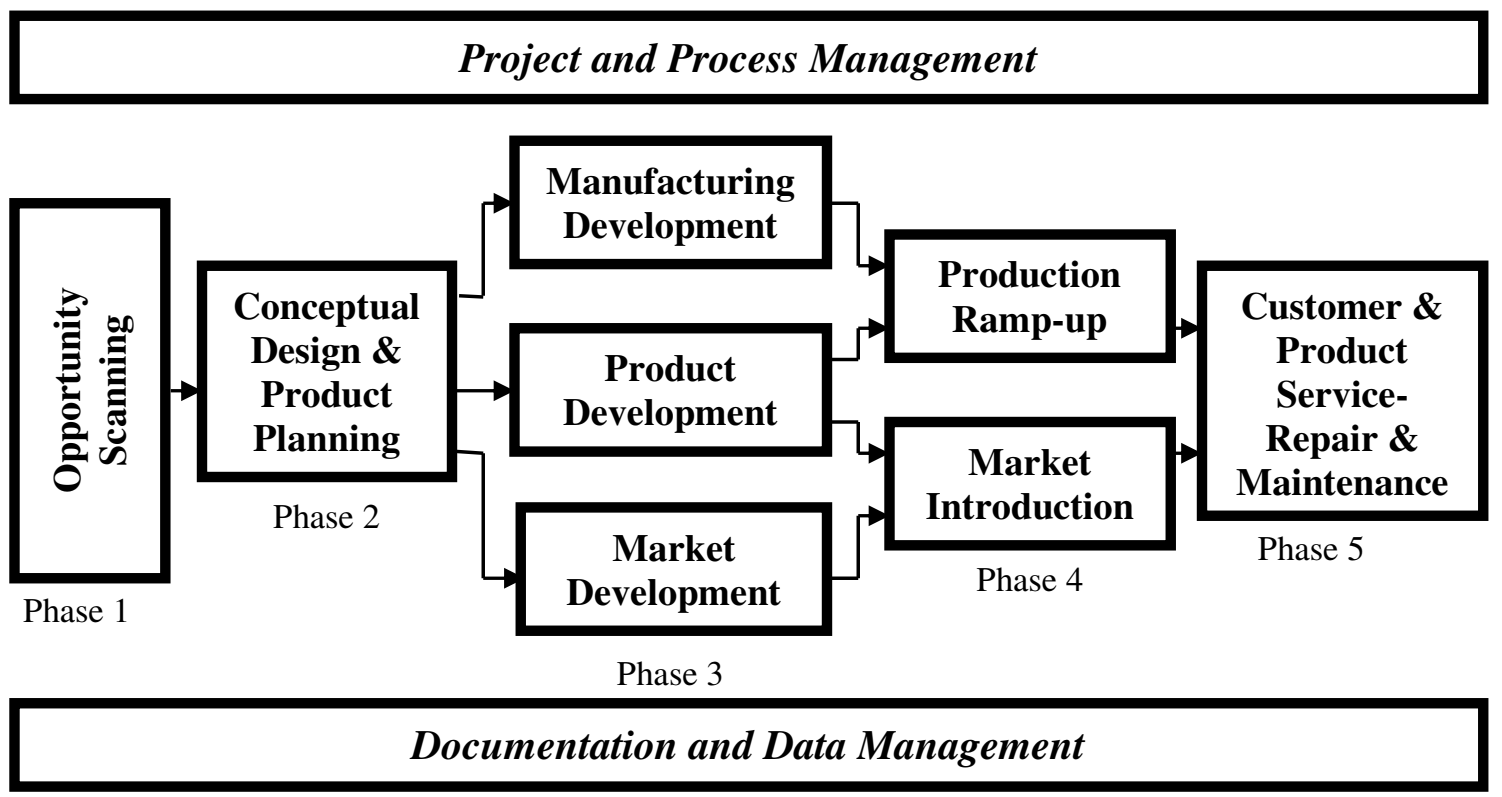

Figure 3. New Product Development Process as Modeled in Lehigh's IPD Program

In Phase 2, Concept Design and Product Planning, the design team takes on the task of developing the market research, customer needs and competitive analysis, business strategy, brainstorming and other creative ways to develop concepts, scan, score and develop these concepts into the technical specifications needed for Phase 3 . Phase 2 is often referred to as the creative "fuzzy front end" but our collective experience has shown that this too is a process that can be taught and experienced.

Phase 3 is the parallel development of the product, manufacturing processes and marketing. This phase is the most familiar to classically trained engineering, business and design faculty. In this phase the team works with the technical specifications form Phase 2 and then develops the hardware and software systems, subsystems and components that comprise the new product or service. Prototypes are developed, fabricated and tested, materials and manufacturing processes, global suppliers are secured.

In Phase 4 the manufacturing system to produce the product and the marketing channels needed to sell the product are ramped up. The product is produced and marketing campaign is launched. In Phase 5 the product is purchased and support services kick in. The investment made many months earlier is now paying off. The product is successful in the market, generates income and the innovation process starts anew. 


\section{B. Overlays of Continuing Activities}

In considering this model for new product development process, it is obvious that many continuous activities run in parallel to these five phases. As shown in Figure 3, these include project management, information and data management. Another obvious overlay is time with time passing from left to right measured in weeks, months or years depending on the industry, product complexity and scale. Other industry dependent overlays include regulatory processes and compliance, intellectual property, competitive benchmarking, technical modeling and simulation, prototype development, risk assessment, financial modeling and resource management including people, space and cash flow.

In addition this model provides an excellent context to overlay the academic objectives and learning opportunities associated with cross disciplinary undergraduate education, particularly as required for ABET accreditation for most undergraduate engineering programs.

\section{Meeting and Exceeding ABET requirements A. Accreditation Board for Engineering and Technology, ABET}

ABET, Inc. is the recognized organization responsible for accreditation of over 2700 education programs in applied science, computing, engineering, and technology at over 550 colleges and universities in the USA. According to ABET [Ref 17] their federation of 30 professional and technical societies is among the most respected accreditation organizations in the U.S., and in turn is recognized by the Council for Higher Education Accreditation, providing leadership and quality assurance in higher education for over 70 years. By involving the professional societies, ABET accreditation assures that a program will meet the quality standards established by the applicable profession. ABET indicates the most important reasons for accreditation as:

- Accreditation helps students and their parents choose quality college programs.

- Accreditation enables employers to recruit graduates they know are well-prepared.

- Accreditation is used by registration, licensure, and certification boards to screen applicants.

Accreditation gives colleges and universities a structured mechanism to assess, evaluate, and improve the quality of their programs.

\section{B. ABET Requirements}

Several of the eight ABET criteria for engineering programs explicitly address the kinds of skills that are needed to succeed as a technical entrepreneur. Criterion 3 states:

"Engineering programs must demonstrate that their students attain:

a) an ability to apply knowledge of mathematics, science and engineering

b) an ability to design and conduct experiments, as well as to analyze and interpret data

c) an ability to design a system, components or process to meet desired needs with realistic constraints such as economic, environmental, social, political, ethical, health and safety, manufacturability and sustainability

d) an ability to function on multi-disciplinary teams

e) an ability to identify, formulate and solve engineering problems

Proceedings of the 2006 American Society for Engineering Education Annual Conference \& Exposition Copyright (O) 2006, American Society for Engineering Education 
f) an understanding of professional and ethical responsibility

g) an ability to communicate effectively

$h$ ) the broad education necessary to understand the impact of engineering solutions in a global economic, environmental, and social context

i) a recognition of the need for, and an ability to engage in life-long learning

j) a knowledge of contemporary issues

k) an ability to use the techniques, skills, and modern engineering tools necessary for engineering practice"

Our approach is to overlay these skills on the new product development process as described above, measure and assess the students' performance and institute bi annual reviews to continuously improve.

In the ABET documents engineering design is defined under Criterion 4 as "the process of devising a system, component, or process to meet desired needs." ABET requires that design be integrated throughout the curriculum (Criteria $4 \mathrm{a}$ and $4 \mathrm{~b}$ ), culminating in a major or capstone design experience (by last sentence under Criterion 4c):

"Students must be prepared for engineering practice through the curriculum culminating in a major design experience based on the knowledge and skills acquired in earlier course work and incorporating engineering standards and multiple realistic constraints."

The original EC2000 (Engineering Criteria 2000) regarding capstone design under Criteria 4 was more stringent, e.g. the last three words of Criterion $4 \mathrm{c}$ listed above, multiple realistic constraints, originally read:

"realistic constraints that include most of the following

considerations: economic; environmental; sustainability;

manufacturability; ethical; health and safety; social; and political."

The list of realistic constraints now appear under Criterion 3c, and is weaker now because (1) they can be satisfied by work in any course (not required under the capstone design) and (2) is just a suggested list rather than having a requirement that most be included:

"Engineering programs must demonstrate that their students attain an ability to design a system, component, or process to meet desired needs within realistic constraints such as economic, environmental, social, political, ethical, health and safety, manufacturability, and sustainability."

Because the requirement for multiple disciplines is included under Criterion $3 \mathrm{~d}$ :

"Engineering programs must demonstrate that their students attain an ability to function on multi-disciplinary teams,"

it can be satisfied by course work other than the capstone design and the multidisciplinary criterion is weaker than interdisciplinary, e.g. it can be satisfied by teams in different sub-areas of the same program. For example, for civil engineering programs, Criterion $3 \mathrm{~d}$ can be satisfied by two civil engineering sub-discipline teams, one in 
structural engineering and the other in soil mechanics. ABET felt that an interdisciplinary teaming requirement would be difficult to include because it relied on cooperation with other department or programs and perhaps beyond the control of the accredited program. Also, many programs expand upon the design requirement by including design criteria under Criterion 8 , additional criteria for individual programs. For example, the civil engineering program criteria include:

"The ability to perform civil engineering design by means of design experiences integrated throughout the professional component of the curriculum

The program must demonstrate that faculty teaching courses that are primarily design in content are qualified to teach the subject matter by virtue of professional licensure, or by education and design experience."

\section{Exceeding the Minimum ABET capstone Design Requirement}

The minimum ABET requirements regarding the capstone design include multiple realistic constraints and engineering standards and includes learning that can occur in previous courses. Specific realistic constraints and multidisciplinary or interdisciplinary teams are not now required provided the program can demonstrate that somewhere in the curriculum the program demonstrates that the students demonstrate the ability to function on a multidisciplinary team.

In the IPD model for technical entrepreneurship, we strive to exceed the minimum ABET requirements of a capstone course by

1. Exceeding the more stringent, original EC 2000 statement of: include most of the following considerations: economic; environmental; sustainability; manufacturability; ethical; health and safety; social; and political in he major culminating (capstone) design course.

2. Exceed the multidisciplinary requirement somewhere in the program by interdisciplinary in the capstone design course

3. Directly measure the students understanding of and ability to apply many of the Criterion $3 \mathrm{~A}-\mathrm{K}$ requirements as they relate to the deliverables required in the new product development process of Figure 3 though a comprehensive set of rubrics, specifically developed for the gradeable moments in these capstone courses [Ref 18].

\section{The Role of the IPD Model in Capstone Courses Across Engineering Disciplines and Academic Programs}

\section{A. Implementation to date}

Since 1996 the IPD model of technical entrepreneurship has been applied to engineering students in Mechanical Engineering and Mechanics, Materials Sciences and Engineering, Integrated Business and Engineering students who can major is any of the engineering programs including Industrial and Systems Engineering, Civil and Environmental Engineering, Chemical Engineering, Electrical and Computer Engineering. In a similar manner Bio Engineering majors with a sub concentration in Mechanical, Electrical and Chemical engineering are required to take the IPD capstones courses. Computer Science and Business majors, whose program does not require ABET approval, also follow a similar model.

Proceedings of the 2006 American Society for Engineering Education Annual Conference \& Exposition Copyright 0 2006, American Society for Engineering Education 
The IPD model has be implemented in the capstone course in these majors with understanding that it can and should be customized to fit specific needs. For example, in many IPD projects, faculty work with industry sponsors to identify the opportunity. In this case the student teams work specifically to validate those opportunities and work primarily on Phases 2 and 3 with the company responsible for Phases 4 and 5.

As an specific example of this customization, in the 2004 a student team worked on a hand grinder project for Ingersoll-Rand's (IR) Tool and Hoist Division with the objective to redesign their current US product for the Asian-Pacific market. The industrial sponsors defined the problem as being primarily "featured based" with instruction for the team to match their main competitors "roll throttle" design as compared to IR's current design that had a "grip-spring-pin" throttle. After several weeks of research, the student team finally reached IR's Asian Pacific marketing head who informed them that the main issue was price, not the actuation. So, the final design focused on removing all of the cost while implementing roll throttle that maintained the safety of the US design. As a result of the project, IR developed an overseas supplier and is now positioned to be a major a player in this market.

\section{B. Entrepreneurship in IBE}

As an alternative to sponsored projects from established companies, the students enrolled in Lehigh's first honor program apply the model to local start ups. Since 2000 students enrolled in Lehigh's Integrated Business and Engineering (IBE) program work with local start-up companies that have been accepted into the Ben Franklin Technical Partners incubator, located on Lehigh's mountain top campus. The IBE students get first hand experience working with practicing entrepreneurs and see first hand the entrepreneurial mind set at work. Together the IBE and entrepreneur are responsible for all five phases of the new product development process. These entrepreneurs generally appreciated the extra help that comes with six eager and bright students. Most teams can make immediate positive impact on the company's bottom line and in several cases the IBE teams have developed successful new products. While the capstone experience for IBE students is differentiated from that of IPD students working for established companies, the teams still focused primarily on Phases 1 through 3 of the new product development model.

Starting in 1999 in an experimental freshmen year IBE course, Professor Ochs, Watkins and Snyder planted the seeds for student entrepreneurs by requiring the IBE student teams to develop their own product idea following the same IPD model as in Figure 3. The end-of-semester requirement for this course is an E-team proposal to the National Collegiate Inventors and Innovators Alliance (NCIIA) annual competition [Ref 19 and Ref 20]. Over the past several years, this built-in course requirement has resulted in five IBE student E-team winners of NCIIA grants that range from $\$ 8 \mathrm{~K}$ to $\$ 20 \mathrm{~K}$ to support the development of what can best be described as "life style" types of products. Table 2 contains a listing of the both Lehigh's Student Entrepreneurship Competition (SEC) winners and the NCIIA E-team projects by year, product Title, grant amount and the majors of the students involved. 


\begin{tabular}{|c|c|c|c|c|}
\hline$\#$ & Year & Title & $\begin{array}{l}\text { Initial } \\
\text { Grants }\end{array}$ & $\begin{array}{c}\text { Engineering \& Other } \\
\text { Majors }\end{array}$ \\
\hline 1 & 2001 & Find Location Instantly ${ }^{1,2}$ & $\$ 15,000$ & $\begin{array}{l}\text { Finance, Mechanical \& } \\
\text { Electrical }\end{array}$ \\
\hline 2 & 2002 & InCrowd Creations $^{1}$ & $\$ 13,500$ & Electrical and Computer \\
\hline 3 & 2002 & No Dip Paintstick $^{1}$ & $\$ 13,600$ & $\begin{array}{l}\text { Marketing, Finance, } \\
\text { Electrical and Computer, } \\
\text { Industrial, Mechanical }\end{array}$ \\
\hline 4 & 2002 & EcoTech Marine $^{1,2}$ & $\$ 18,738$ & $\begin{array}{l}\text { Civil and Environmental } \\
\text { Material Science }\end{array}$ \\
\hline 5 & 2002 & Soda Sentry (SOS) ${ }^{1,2}$ & $\$ 9,241$ & Mechanical \& Industrial \\
\hline 6 & 2003 & Free Feet $^{1}$ & $\$ 13,500$ & Mechanical Engineering \\
\hline 7 & 2003 & Better batteries $^{1}$ & $\$ 2,500$ & Mechanical Engineering \\
\hline 8 & 2004 & hField - wifi antenna ${ }^{2}$ & $\$ 17,500$ & Computer Engineering \\
\hline 9 & 2004 & Model Plane Propulsion ${ }^{2}$ & $\$ 2,500$ & Mechanical Engineering \\
\hline 10 & 2004 & Snow Sport speed vision $^{2}$ & $\$ 2,500$ & Mechanical Engineering \\
\hline 11 & 2005 & Psyeron $^{2}$ & $\$ 2,500$ & Computer Science \\
\hline 12 & 2005 & Baxter Audio $^{2}$ & $\$ 2,500$ & Electrical \& Computer \\
\hline 13 & 2005 & Sleep Detection $^{2}$ & $\$ 2,500$ & Mechanical \\
\hline 14 & 2005 & Soccer without borders $^{2}$ & $\$ 2,500$ & $\begin{array}{l}\text { Architecture, Global } \\
\text { Education Leadership }\end{array}$ \\
\hline 15 & 2005 & Bidgrid $^{2}$ & $\$ 2,500$ & Finance \\
\hline 16 & 2005 & Viddler Interactive $^{2}$ & $\$ 2,500$ & $\begin{array}{l}\text { Computer Science and } \\
\text { Business }\end{array}$ \\
\hline 17 & 2005 & Orion Securities $^{2}$ & $\$ 2,500$ & $\begin{array}{l}\text { Industrial, Mechanical \& } \\
\text { Physics }\end{array}$ \\
\hline
\end{tabular}

Table 2. NCIIA ${ }^{1}$ and Student Entrepreneurship Competition ${ }^{2}$ winners 2001-2005

The typical question asked at this point is "How many businesses were launched and are they still in business?" They answer is simple - only two to date. The reasons for this are many, including being unable to secure funding and being beaten to the market. Another unexpected cause is based on the student's success. As is typical of high performance people, these E-team students are highly recruited with many receiving low six figure starting salaries and this for new graduates with only a BS degree! As was quoted on several occasions by student entrepreneurship winners, "I need to pay back my student loans for my Lehigh degree, not incur more debt in order to start a business!"

Nevertheless, the learning that has occurred in these courses has been documented and is an academic success that will certainly bare fruit in the future. To quantify the long term effects of these types of experiential courses, the engineering college has started a longitudinal study to track the progress of these exceptional students.

\section{The Entrepreneurship Minor}

With the development of the entrepreneurship minor, the number of engineering and other students interested in entrepreneurship as a career has increased by an order of

Proceedings of the 2006 American Society for Engineering Education Annual Conference \& Exposition Copyright (C) 2006, American Society for Engineering Education 
magnitude. From the plot courses first offered in the spring 2005 to a small group of students, there are now over 80 students enrolled in the two entrepreneurship courses offered each semester. These courses have become a feeder system for Lehigh's campus wide Student Entrepreneurship Competition. In the fall of 2005 seven student teams received funding from Lehigh for the development of their ideas and to create a startup venture (\#11 to \#17 in Table 2).

\section{Conclusion, Lessons Learned and Next Steps}

In conclusion the new product development process has been a model for capstone courses in several engineering programs for the past several years. While most programs focus on phases one through three as shown in Figure 3, the student entrepreneur must take responsibility for developing all five phases. Table 3 lists the five stages and delineates the academic programs, sponsors, funding levels and sources required for a typical project. To date several academic programs have committed to and use this model including Mechanical Engineering and Mechanics, Materials Engineering, Integrated Business and Engineering, Computer Science and Business, Bio Engineering and Design Arts. Several business majors including Marketing and Management, Supply Chain Management, Management Information Systems encourage their students to enroll in the IPD capstone courses as one of the options for their required capstone courses.

Despite the success of these programs or perhaps because of it, several engineering departments are still reluctant to get involved in entrepreneurial capstone projects. Many engineering faculty are concerned with the time commitment required for these projects and they are insecure with doing open ended projects outside their areas of expertise. This is particularly acute when dealing with young assistant professors who are focused on establishing their reputations in research, usually at the expense of undergraduate education. With fully $1 / 3$ of the Lehigh's engineering faculty newly hired in the past three years, this does not bode well for the future and will require college level leadership to make sure undergraduate entrepreneurship education for engineers flourishes.

Also our self assessment has shown that we are in desperate need of entrepreneurship education at the faculty and graduate levels. To that end Lehigh has established a new office of Technology Transfer and Entrepreneurship Education as part of the University's Office of Research. The approach to faculty education in entrepreneurship and commercialization of University IP will need a lot of work and resources in the near future to support the education of the newly hired research-oriented young faculty.

A great resource that has helped us to success in this experiential education has been the use of Professors of Practice. Professors of Practice are senior part-time teaching faculty, who have been in industry and have experienced the entrepreneurial mind set and the new product development process. These experience entrepreneurs are committed to giving our undergraduates, the appropriate attention, mentoring and often tough love while bring real world experience and professional behavior to the capstone classes. 


\begin{tabular}{|c|c|c|c|c|c|c|}
\hline & Phases & 1 & 2 & 3 & 4 & 5 \\
\hline & $\begin{array}{l}\text { Process } \\
\text { Stages }\end{array}$ & $\begin{array}{c}\text { Opportunity } \\
\text { Assessment } \\
\text { and Business } \\
\text { Plan } \\
\text { Development }\end{array}$ & $\begin{array}{l}\text { Product or } \\
\text { Process } \\
\text { Conceptual } \\
\text { Design and } \\
\quad \text { Plan } \\
\end{array}$ & $\begin{array}{c}\text { Product, } \\
\text { Mfg Process, } \\
\text { and Market } \\
\text { Development }\end{array}$ & $\begin{array}{c}\text { Company } \\
\text { Launch } \\
\text { Mfg, } \\
\text { Market } \\
\text { Ramp up } \\
\end{array}$ & $\begin{array}{l}\text { Product } \\
\text { Service } \\
\text { \& Repair }\end{array}$ \\
\hline $\begin{array}{l}\text { Project } \\
\text { Sponsors }\end{array}$ & $\begin{array}{c}\text { Target } \\
\text { Programs }\end{array}$ & \multicolumn{5}{|c|}{ (Yes $=$ student participation, No = not required of students $)$} \\
\hline $\begin{array}{l}\text { Established } \\
\text { Company }\end{array}$ & $\begin{array}{c}\text { IPD } \\
\text { CSB } \\
\text { Bio Engr } \\
\text { Design Arts }\end{array}$ & Yes & Yes & Yes & No & No \\
\hline $\begin{array}{c}\text { Ben Franklin } \\
\text { Start Up } \\
\text { Companies }\end{array}$ & $\begin{array}{l}\text { IBE and } \\
\text { Graduate } \\
\text { IPD }\end{array}$ & Yes & Yes & Yes & No & No \\
\hline $\begin{array}{c}\text { IPD } \\
\text { Program and } \\
\text { NCIIA } \\
\end{array}$ & $\begin{array}{l}\text { E-Teams } \\
\text { Entrep } \\
\text { Minors } \\
\end{array}$ & Yes & Yes & Yes & Yes & Yes \\
\hline $\begin{array}{c}\text { Office of } \\
\text { Tech } \\
\text { Transfer, } \\
\text { Students } \\
\text { Companies }\end{array}$ & $\begin{array}{c}\text { Entrep } \\
\text { Graduate } \\
\text { IPD } \\
\text { MBA } \\
\text { V-Series } \\
\end{array}$ & Yes & Yes & Yes & Yes & Yes \\
\hline Funding & \$\$ Levels & $\$ 2 \mathrm{~K}$ to $\$ 5 \mathrm{~K}$ & $\begin{array}{l}\$ 5 \mathrm{~K} \text { to } \\
\$ 20 \mathrm{~K}\end{array}$ & $\begin{array}{l}\$ 20 \mathrm{~K} \text { to } \\
\$ 200 \mathrm{~K}\end{array}$ & $\begin{array}{l}\$ 200 \mathrm{~K} \text { to } \\
\$ 2 \mathrm{M}\end{array}$ & $\begin{array}{l}\$ 200 \mathrm{~K} \text { to } \\
\$ 2 \mathrm{M}\end{array}$ \\
\hline Funding & Sources & $\begin{array}{l}\text { IPD program } \\
\text { Entrep Minor } \\
\text { Companies } \\
\text { State Agencies }\end{array}$ & $\begin{array}{c}\text { Companies } \\
\text { IPD } \\
\text { program } \\
\text { NCIIA } \\
\text { Grants } \\
\text { State } \\
\text { Agencies }\end{array}$ & $\begin{array}{c}\text { SBIR Grants } \\
\text { Friend/Family } \\
\text { Credit Cards } \\
\text { State Agencies } \\
\text { Angel } \\
\text { Investors }\end{array}$ & $\begin{array}{l}\text { Venture } \\
\text { Funds } \\
\text { Angel } \\
\text { Investors } \\
\text { Bank } \\
\text { Loans } \\
\text { Self } \\
\text { Funded } \\
\end{array}$ & $\begin{array}{c}\text { Income } \\
\text { from Sales } \\
\text { Stock } \\
\text { Sales } \\
\text { Bank } \\
\text { Loans }\end{array}$ \\
\hline
\end{tabular}

Table 3. Types of projects by sponsor and students for each of the stages in the new product development process (Refer to Figure 3 for the Five Phases)

We will continue to develop an entrepreneurial environment, culture and the infrastructure needed to support student entrepreneurs. The goal is to continue to infect established programs in every undergraduate and graduate engineering program with the IPD model of technical entrepreneurship and encourage all interested student to become part of the entrepreneurship minor. To accomplish this goal we will need to redouble our effort at advertising the minor program to current and incoming students, upgrade the University's web page to highlight the minor and work with admissions and undergraduate recruiters to promote this differentiating characteristic of a Lehigh education that is open to all majors.

\section{References}

1. Streeter Deborah H., Jaquette, John P., and Hovis, Kathryn, "University - wide Entrepreneurship Education: Alternate Models and current trends," Cornell University, WP 2002, March 2002. 
2. Todd A. Watkins,, John B. Ochs and Berrisford W. Boothe, "Integrating Design Arts, Engineering and Business Curricula through Multidisciplinary product Design Projects," Proceeding from the Second Annual NCIIA Conference, Washington DC, March 13-15, 1998.

3. Ochs, John, B, Watkins, Todd A, and Boothe, Berrisford W., "Creating a Truly Multidisciplinary Entrepreneurial Educational Environment," Journal Engineering Education, October 2001, 577-83.

4. Ochs, John, B, Watkins, Todd A. and Mitchell, Graham, "Integration of Lehigh's Entrepreneurship Minor into the Undergraduate Engineering and Business Curricula," Abstract in the Proceedings of the 2005 American Society for Engineering Education Annual Conference \& Exposition, June 2005.

5. Ochs, JB and Wolkoff, Regina L "Global collaboration," The Journal of British Association for Open Learning, Issues 51, Jan 2000

6. Van Kollenburg, Van Schenk, Brill, Schouten, Mulders, Ochs, Zirkel, Kimura and Klette, "Collaborative Engineering Experiences, " Proceedings of the Engineering and Product Design Education Conference 2000, University of Sussex, UK, September 6 and 7, 2000.

7. Ochs, John B., NASA/CAPE “International and Regional IPD Projects," subcontract to grant \# 991182, March 2000.

8. Ochs, John B., and Boothe, Berrisford, W., "Integrated Product Development at Lehigh University," Congressional Grant from the Department of Education to Lehigh University, Grant \# P116Z000033, Jan 2000 to Aug 2002.

9. Ochs, John B., and Boothe, Berrisford, W., "Integrated Product and Process Development at Lehigh University," Congressional Grant from the Department of Education to Lehigh University, Grant \# P116Z000033, September 2001 to Aug 2003.

10. Ochs, John B. and Watkins, Todd A. "Demonstration Project Linking Academic Entrepreneurial Courses with Dislocated and New Entrant Workers for Self Employment and New Company Start-ups," Department of Labor grant, Jan 2001 to August 2003.

11. Ochs, John B, Watkins, Todd A. and Boothe, Berrisford, W., "Attracting Under Represented Students to Engineering through Career Awareness Programs (CAP)," Abstract. Proceedings of the American Society of Engineering Education Conference, Montreal Canada, June 2002.

12. Kloss, Bryan, Christman, Leah and Ochs, John, B., "Implementing Technical Entrepreneurship as a Required Junior Course for all Students at Northwestern Lehigh High School," Proceedings of the 2005 American Society for Engineering Education Annual Conference \& Exposition, June 2005.

13. Stevenson, Howard H., A Perspective on Entrepreneurship, Harvard Business School Working Paper \#9-384-131, Boston MA, 1983.

14. Stevenson, Howard H., The Heart of Entrepreneurship, Harvard Business Review, March-April, 1985, pp 85-94.

15. Stevenson, Howard H., Why Entrepreneurship Has Won!, Coleman White Paper, US Association for Small Business and Entrepreneurship, USASBE Plenary Address, February 17, 2000, online at http://www.usasbe.org/pdf/CWP-2000-stevenson.pdf. 
16. Entrepreneur Magazine, Top 100 Entrepreneurial Colleges for 2004, summary rankings online at http://www.entrepreneur.com/topcolleges/0,6441,,00.html and also details at http://www.entrepoint.com

17. Accreditation Board for Engineering and Technology (ABET). www.abet.org

18. Getzler-Linn, Lisa, Ochs, John B., Watkins, Todd A., "Program and Student Performance Assessment in Team-Based Project Courses with Focus on Technical Entrepreneurship and Product Development: Lehigh University's IPD Program.” Proceeding from the January 2006 USASBE Conference, Tucson Az, January 2006.

19. Ochs, John, B, Watkins, Todd A, and Boothe, Berrisford W., "Cultivating an Entrepreneurial Spirit through Cross-disciplinary Student teams in Freshman Projects Course," Proceedings of the American Society of Engineering Education Conference, Montreal Canada, June 2002.

20. National Collegiate Inventors and Innovators Alliance (NCIIA) www.nciia.org

\section{JOHN B. OCHS}

\section{Author's Biographies}

John B. Ochs is Professor of Mechanical Engineering at Lehigh and Director of the Integrated Product Development Program (IPD), which he co-founded with Dr. Watkins in 1994. He is the past chairman the Entrepreneurship division of the American Society for Engineering Education. From 1985-95 Dr. Ochs did extensive industry consulting and was involved in the start up of three companies. In 1996 the pilot courses IPD won the American Society of Mechanical Engineers' curriculum innovation award and in 1997 IPD won the Newcomen Society award for the promotion of America's freeenterprise system. Dr. Ochs holds a MS and Ph.D. from The Pennsylvania State University.

\section{GERARD P. LENNON}

Gerard P. Lennon is a Professor of Civil and Environmental Engineering. He earned a BS from Drexel University, and an MS and a PhD from Cornell University. He authored over 70 papers, and his groundwater research has been funded by five different federal and state agencies, including an NSF investigation of ocean-bottom geothermal vents in the Alvin Submarine. As a member of the American Society of Civil Engineers he organized an International Groundwater Symposium and was associate editor. He led his department ABET accreditation committee activities for eight years until taking over that role as Associate Dean of the College of Engineering and Applied Science at Lehigh in 2006, and is now the lead person in the college for accreditation activities.

\section{TODD A. WATKINS}

Todd A. Watkins is Associate Professor in the College of Business and Economics and Director of the Institute for Regional Political Economy at Lehigh. He holds Ph.D. and M.P.P. degrees from Harvard and a B.S. from the University of Rochester. He previously worked in optical design and optical manufacturing engineering at Eastman Kodak. His research and teaching involves the economics of innovation, manufacturing and new product development. From 1999 to 2002, as the Faculty Fellow to the Provost, he was responsible for promoting innovative, inquiry-based curriculum campus wide. For seven consecutive years, teams advised by Dr. Watkins have won start-up grants in national 
competitions for collegiate technology entrepreneurship. He chaired the joint committee that developed the entrepreneurship minor described here.

\section{GRAHAM R. MITCHELL}

Graham R. Mitchell is a Professor of Practice and Director of the campus-wide Entrepreneurship minor program housed in Lehigh's College of Business and Economics. From 1998 to 2003 Graham Mitchell was the Bladstrom Visiting Professor at the Wharton School of the University of Pennsylvania, and Director of the Wharton Program in Technological Innovation. Between 1993 and 1997 he was United States Assistant Secretary of Commerce for Technology Policy. Prior to that, he was for 12 years with the General Electric. A co-founder of a start up in wireless communication, he is a member of several boards. He is author of over 40 papers and studies on technology, management, and policy. He holds 7 U.S. patents, and is a recipient of several major honors. He holds a B.Sc. and Ph.D. in Electrical Engineering from the University of Westminster, London. 